\title{
Baltic - Nordic Universities in the EU Research and Innovation Programme Horizon 2020
}

\section{Dina Bērzina}

Institute of Atomic Physics and Spectroscopy, University of Latvia, Latvia.

\begin{abstract}
This study looks at the research education in universities and is aimed at assessment of the Baltic-Nordic Higher Education Establishments' participation to the EU Horizon 2020 Framework Programme on basis of the open source data. The author analyses university interest in Horizon 2020 support for doctoral students' training, correlation between university PhD intensity and involvement in research projects, correlation between Horizon 2020 success and World university rankings, participation comparison of Nordic universities versus the Baltic ones. A brief overview of universities' commitment to Sustainable development goals is also included.

The study concludes that Nordic universities are more thoroughly engaged than the Baltic ones and are taking advantage of the Horizon 2020 opportunities; however, Estonia has a remarkable success. Although Nordic universities are looking for collaboration partners further into Western Europe than to the neighbours across the Baltic Sea, for teaming activities Baltic universities choose Nordic mentors. Nordic universities are more involved in activities leading to excellent research. On contrary - in many cases participation of Baltic universities is limited to coordination of research activities without a direct access to the leading European science communities and respective possibilities for students.
\end{abstract}

Keywords: Scientific and research education; Horizon 2020; Baltic-Nordic universities. 


\section{Introduction}

Fundamental principles laid down in the Magna Charta of the European Universities (Magna Charta Universitatum, 1988) emphasise close relationship of tuition with research: 'Teaching and research in universities must be inseparable'. Therefore, in parallel to academic education, universities involve students also in research activities thus enriching their level of knowledge.

The major research and innovation programme Horizon 2020 is open to everyone. Higher Education Establishments (HES) are top beneficiaries of this programme for both participations (33\%) and EU contribution (39\%) received.

This study is targeted at assessment of the Baltic-Nordic HES participation to the Horizon 2020 activities based on open data: Dashboard (2020), Cordis (2020), Eurostat (2020), and ETER (2020). However, online databases are updated regularly, and the current study reflects results as of March 2020.

Earlier correlation for Horizon 2020 participation success and 15-year old students' mean performance in OECD Programmes for International Student Assessment was analysed by Geske and Bērziņa (2017) concluding that there are no decisive factors responsible for success in the Horizon 2020.

\section{Data Sample selection}

A multi-level selection has been chosen for analysing HES performance according to country group, performance in Horizon 2020 and university's research profile.

This survey focuses on Baltic - Nordic country group. In terms of Horizon 2020 it means: three 'old' member states (Denmark, Finland, and Sweden), three 'new' member states (Estonia, Latvia, and Lithuania) and two associated countries (Iceland and Norway). All of them are participants of the Nordic - Baltic space for higher education and research.

The top-500 Horizon 2020 performing HES have been selected (Dashboard, 2020): 52/51 ${ }^{1}$ organisations fit the sample requirements: 8 establishments in Denmark, Estonia - 4, Finland - 10, Iceland - 1, Latvia - 3/2, Lithuania - 2, Norway - 8, and Sweden - 16.

Further, according to the ETER - European tertiary education register (last data from 2016), only universities identifying themselves as research ones have been chosen for the study. Two universities in Norway and one in Sweden are excluded.

\footnotetext{
${ }^{1}$ Horizon 2020 data for University of Latvia and Institute of Solid State Physics, University of Latvia are merged
} 
Considering the three above-mentioned prerequisites, 48 universities would form the study sample. However, due to space limitation only up to three (according to H2020 ranking) per country are included in the current study (Tab. 1). All Nordic HES (with exception of Iceland) rank among the top-100 universities according to Horizon 2020 ranking; two Estonian universities are in the second hundred. The list ends on Latvian and Lithuanian universities.

Table 1. Baltic - Nordic universities chosen for the study and their international ranking.

\begin{tabular}{|c|c|c|c|c|c|c|c|}
\hline $\mathrm{H}^{2020^{2}}$ & THE $^{3}$ & $\mathbf{Q S}^{4}$ & CWUR $^{5}$ & $\begin{array}{c}\text { Institution Name } \\
\text { (English) }\end{array}$ & Country & Acronym & $\begin{array}{c}\text { National } \\
\text { rank }^{5}\end{array}$ \\
\hline 5 & 101 & 81 & 39 & $\begin{array}{l}\text { University of } \\
\text { Copenhagen }\end{array}$ & DK & KU & 1 \\
\hline 11 & 184 & 112 & 213 & $\begin{array}{l}\text { Technical } \\
\text { University of } \\
\text { Denmark }\end{array}$ & DK & DTU & 3 \\
\hline 20 & 115 & 145 & 95 & Aarhus University & DK & $\mathrm{AU}$ & 2 \\
\hline 21 & 41 & & 42 & Karolinska Institute & SE & KI & 1 \\
\hline 23 & 96 & 107 & 134 & $\begin{array}{c}\text { University of } \\
\text { Helsinki }\end{array}$ & FI & HY & 1 \\
\hline 25 & 96 & 92 & 141 & Lund University & SE & LU, SE & 4 \\
\hline 32 & 131 & 119 & 56 & University of Oslo & $\mathrm{NO}$ & $\mathrm{UiO}$ & 1 \\
\hline 34 & $201-250$ & 98 & 118 & $\begin{array}{l}\text { KTH Royal } \\
\text { Institute of } \\
\text { Technology }\end{array}$ & SE & KTH & 3 \\
\hline 48 & 184 & 134 & 310 & Aalto University & FI & AYO & 2 \\
\hline 58 & $401-500$ & 359 & 162 & $\begin{array}{l}\text { Norwegian } \\
\text { University of } \\
\text { Science and } \\
\text { Technology }\end{array}$ & NO & NTNU & 2 \\
\hline
\end{tabular}

\footnotetext{
${ }^{2}$ Dashboard, 2020

${ }^{3}$ The Times Higher Education World University Rankings 2020

${ }^{4}$ Quacquarelli Symonds World University rankings 2020

${ }^{5}$ Center for World University Rankings 2019-2020
} 


\begin{tabular}{|c|c|c|c|c|c|c|c|}
\hline H2020 2 & THE $^{3}$ & $\mathbf{Q S}^{4}$ & CWUR $^{5}$ & $\begin{array}{c}\text { Institution Name } \\
\text { (English) }\end{array}$ & Country & Acronym & $\begin{array}{c}\text { National } \\
\text { rank }^{5}\end{array}$ \\
\hline 69 & $201-250$ & 163 & 261 & $\begin{array}{l}\text { University of } \\
\text { Bergen }\end{array}$ & $\mathrm{NO}$ & $\mathrm{UiB}$ & 3 \\
\hline 78 & $251-300$ & 395 & 376 & $\begin{array}{l}\text { Tampere } \\
\text { University }^{6}\end{array}$ & FI & TaY & 4 \\
\hline 104 & $301-350$ & 301 & 502 & University of Tartu & $\mathrm{EE}$ & TÜ & 1 \\
\hline 190 & $801-1000$ & $\begin{array}{l}601- \\
650\end{array}$ & 1273 & $\begin{array}{c}\text { Tallinn University } \\
\text { of Technology }\end{array}$ & $\mathrm{EE}$ & TTÜ & 2 \\
\hline 214 & $351-400$ & --- & 508 & $\begin{array}{l}\text { University of } \\
\text { Iceland }\end{array}$ & IS & $\mathrm{HI}$ & 1 \\
\hline$\sim 207$ & $\begin{array}{l}801- \\
1000\end{array}$ & $\begin{array}{c}801- \\
100 \\
0\end{array}$ & 1490 & Jniversity of Latvia & LV & LU, LV & 1 \\
\hline 301 & $801-1000$ & $\begin{array}{l}801- \\
1000\end{array}$ & --- & Tallinn University & $\mathrm{EE}$ & TLÜ & \\
\hline 307 & $1001+$ & $\begin{array}{l}701- \\
750\end{array}$ & --- & $\begin{array}{l}\text { Riga Technical } \\
\text { University }\end{array}$ & LV & RTU & \\
\hline 361 & $1001+$ & $\begin{array}{l}751- \\
800\end{array}$ & 1631 & $\begin{array}{c}\text { Kaunas University } \\
\text { of Technology }\end{array}$ & LT & KTU & 3 \\
\hline 385 & $801-1000$ & 458 & 703 & Vilnius University & $\mathrm{LT}$ & VU & 1 \\
\hline
\end{tabular}

\section{Horizon 2020 activities}

The latest official evaluation of the Horizon 2020 is available from 2017, and separate flash sheets from 2018 - 2019 (EC Horizon 2020 programme analysis, 2020). Published survey data differ from today's; although, some trends remain throughout the programme. This study looks at Baltic - Nordic HES participation in early 2020 for several selected topics.

\subsection{Country collaboration and success}

Figure 1 reflects relative collaborations (i.e., percentage of project partners from the respective country). Obviously, that for all selected counties Germany is the most frequent

\footnotetext{
${ }^{6}$ Tampere University was created in January 2019 by merging the University of Tampere and Tampere University of Technology
} 
partner due to its size ( $1^{\text {st }}$ line: around $10 \%$ of collaborations), but for Germany Baltic countries is a minor partner ( $1^{\text {st }}$ column, collaboration below $\left.1 \%\right)$. But noteworthy is the country self-cooperation (highlighted diagonal boxes): the 'big-5' countries go for projects with more involved participants form the country (collaboration $\sim 9 \%$ ), while for majority cases participants from Baltics are included as single country representatives in the projects.

Although Sweden is the most retained (above 3\% of EC total contribution) Baltic - Nordic country as the largest one (Worldometer, 2020), other Nordic counties are more successful with respect to EU contribution per capita. Iceland, the smallest country in the sample, has the most successful participants $(21 \%)$ and the highest EU contribution per capita (338€). Also, Iceland is the 'most Baltic - Nordic' country: 19\% of its project partners come from the region. Baltic countries are far behind the Nordic neighbours. However, Estonian success is remarkable - contribution per capita is higher than in UK, France, Spain and Italy.

\begin{tabular}{|c|c|c|c|c|c|c|c|c|c|c|c|c|c|c|c}
\hline & DE & UK & FR & ES & IT & NL & BE & SE & DK & FI & NO & EE & IS & LV & LT \\
\hline DE & 9 & 14 & 13 & 12 & 12 & 14 & 12 & 13 & 12 & 13 & 11 & 9 & 9 & 9 & 10 \\
\hline UK & 10 & 6 & 9 & 9 & 9 & 9 & 8 & 9 & 10 & 7 & 8 & 7 & 9 & 5 & 6 \\
\hline FR & 11 & 11 & 9 & 11 & 11 & 10 & 10 & 10 & 9 & 10 & 10 & 7 & 9 & 8 & 9 \\
\hline ES & 10 & 10 & 11 & 9 & 12 & 9 & 10 & 10 & 9 & 10 & 10 & 9 & 6 & 7 & 8 \\
\hline IT & 10 & 10 & 10 & 11 & 9 & 9 & 9 & 9 & 8 & 9 & 8 & 9 & 8 & 7 & 9 \\
\hline BE & 5 & 7 & 6 & 6 & 6 & 6 & 8 & 6 & 7 & 6 & 6 & 6 & 5 & 6 & 5 \\
\hline SE & 4 & 3 & 3 & 3 & 3 & 3 & 3 & 4 & 4 & 4 & 4 & 3 & 4 & 3 & 3 \\
\hline DK & 2 & 2 & 2 & 2 & 2 & 2 & 2 & 2 & 4 & 2 & 3 & 3 & 3 & 2 & 2 \\
\hline FI & 2 & 2 & 2 & 2 & 2 & 2 & 2 & 3 & 2 & 4 & 3 & 3 & 3 & 3 & 3 \\
\hline NO & 2 & 2 & 2 & 2 & 2 & 2 & 2 & 2 & 3 & 2 & 4 & 2 & 5 & 2 & 2 \\
\hline EE & 0.4 & 0.4 & 0.3 & 0.5 & 0.5 & 0.5 & 0.5 & 0.5 & 0.8 & 0.7 & 0.6 & 2 & 0.7 & 1 & 1 \\
\hline IS & 0.2 & 0.2 & 0.2 & 0.1 & 0.2 & 0.2 & 0.2 & 0.2 & 0.4 & 0.3 & 0.6 & 0.3 & 3 & 0.3 & 0.2 \\
\hline LV & 0.3 & 0.2 & 0.3 & 0.3 & 0.3 & 0.4 & 0.5 & 0.4 & 0.5 & 0.5 & 0.4 & 1 & 0.6 & 2 & 1 \\
\hline LT & 0.4 & 0.3 & 0.4 & 0.3 & 0.4 & 0.4 & 0.5 & 0.4 & 0.5 & 0.5 & 0.5 & 1 & 0.5 & 1 & 1 \\
\hline $\begin{array}{c}\text { Total for B-N, \% } \\
\text { H20 application }\end{array}$ & 19 & 17 & 21 & 16 & 15 & 19 & 20 & 17 & 16 & 15 & 18 & 15 & 21 & 15 & 15 \\
\hline $\begin{array}{c}\text { success-17\% } \\
\text { EU contribution, \% }\end{array}$ & 15 & 13 & 11 & 9 & 8 & 8 & 5 & 3.4 & 2.6 & 2.2 & 2.2 & 0.38 & 0.23 & 0.15 & 0.14 \\
\hline $\begin{array}{c}\text { EU contribution } \\
\text { per capita, } €\end{array}$ & 1318 & 95 & 84 & 99 & 70 & 229 & 220 & 171 & 226 & 207 & 207 & 144 & 338 & 41 & 25 \\
\hline
\end{tabular}

Figure 1. Relative collaboration, success and contribution for selected countries (\%). Source: Cordis (2020).

\subsection{Excellent science and Enhancement of educational programmes}

Projects under Excellent science consolidate research and promote competitiveness on a global scale. The best HES invest efforts for this pillar; however, Baltic universities are seriously lagging behind the Nordic neighbours (Fig. 2). Hereinafter data are provided in percentage of the 'reference' projects against the total number of projects. 


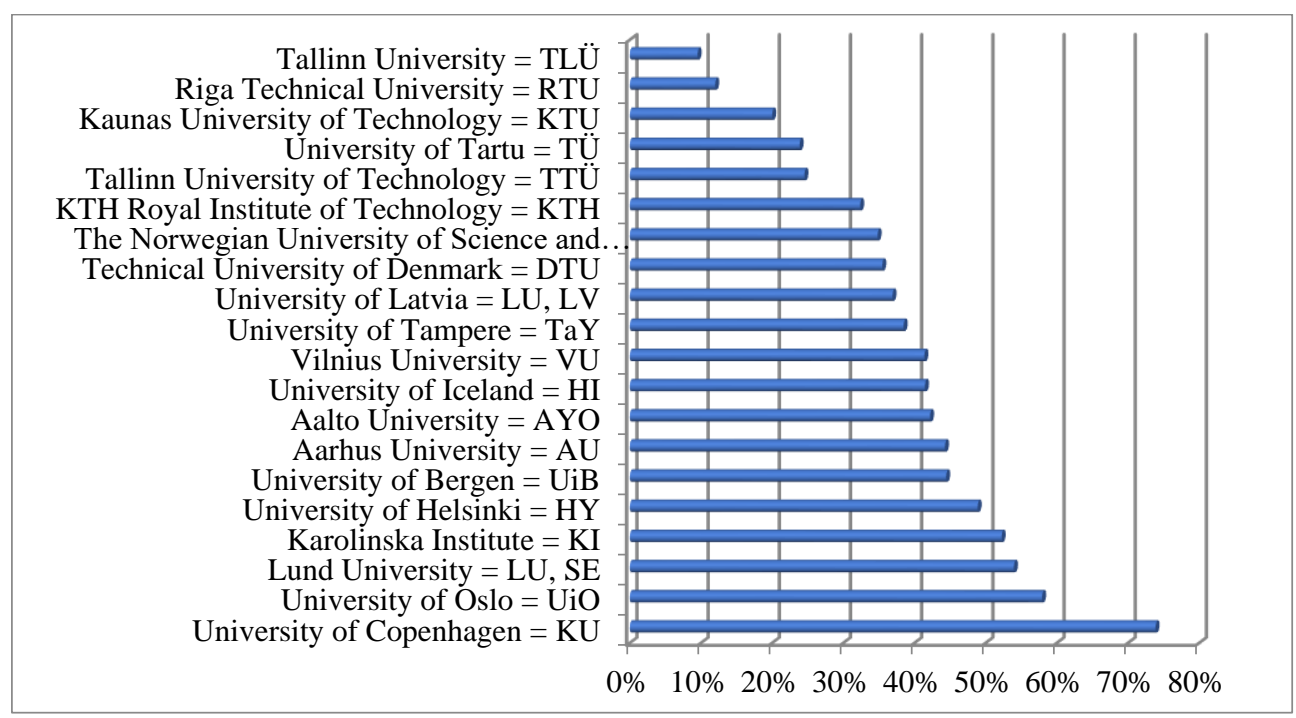

Figure 2. University involvement in Excellent science projects (\%). Source: Dashboard (2020).

Horizon 2020 foresees a special activity co-funded with national governments for advancing national/regional/international programmes for Doctorate and Post-doc researchers' training. By early 2020, 87 such projects have been supported (Dashboard, 2020); about a quarter of them have participants from Baltic - Nordic countries (mainly Nordic): Finland - 20, Sweden -19 , Denmark - 7, Iceland and Norway -2 for each, Estonia - 1. The top-listed universities (Tab. 1) are also the most engaged for this activity. Based on participation intensity in Excellent science projects, it is obvious - Nordic HES have more opportunities for promotion of students' scientific and research education.

\subsection{Research and innovation versus Coordination and support activities}

Research and innovation projects (RIA) are aimed at development of a new knowledge versus coordination and support actions (CSA), which do not enclose any research activities; therefore, scientists are more interested in the collaborative research. There is no significant difference in the share of research projects among Baltic - Nordic universities (grey bars, Fig. 3). However, when involvement in Excellent science and research projects is aggregated (Fig. 2 and grey bars Fig. 3), Nordic universities are far ahead. Therefore, it could be concluded that scientists (and thus also students) from Baltic universities are less integrated into the European Research Area. The said is reflected also by considerably lower citation index (THE, 2020) for Baltic researchers.

Yet, Baltic participants are thoroughly involved in research supporting activities - CSAs, i.e.: establishment of thematic research networks, conducting of studies, etc. (blue bars, Fig. 3). 


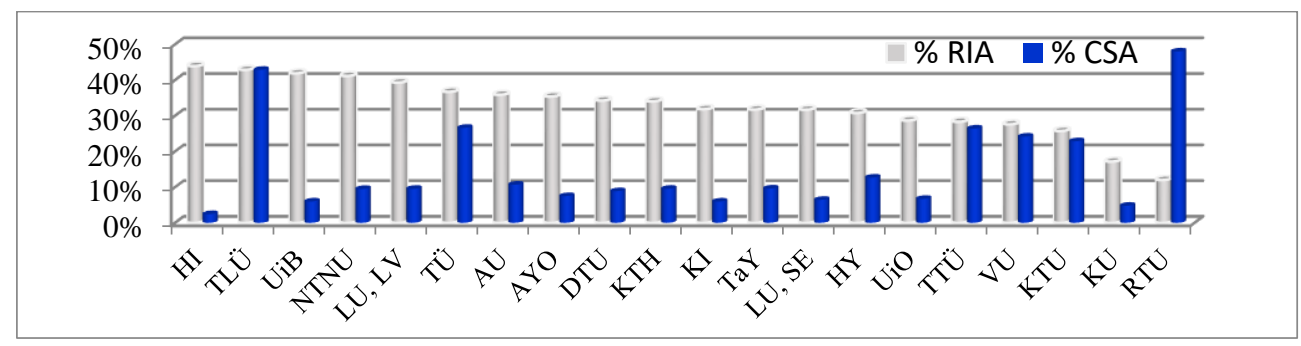

Figure 3. Involvement in research (RIA) and coordination-support (CSA) projects (\%). Source: Dashboard (2020)

\subsection{Spreading excellence and Widening participation}

Estonia, Latvia and Lithuania belong to so called 'widening countries' eligible for special Horizon 2020 support actions. The most influential of them are Teaming activities aimed at consummating existing research centres in 'widening countries' through coupling with leading European research institutions.

Baltic countries' efforts have resulted in 2 teaming projects for Latvia (3 universities) and one for Estonia. Two of three Baltic teams have chosen mentors form leading research centres Nordic countries (Tab. 2): here Baltic - Nordic neighbour links work well.

Table 2. Baltic - Nordic Teaming activities

\begin{tabular}{llll}
\hline Project & Baltic participants & Nordic participants & Other participants \\
\hline CAMART $^{2}$ & $\begin{array}{c}\text { Institute of Solid State Physics, } \\
\text { University of Latvia, LV }\end{array}$ & $\begin{array}{c}\text { KTH Royal Institute of } \\
\text { Technology, SE } \\
\text { RISE ACREO, SE }\end{array}$ & \\
& & RISE Research Institutes \\
of Sweden, SE & \\
BBCE & Riga Technical University, LV & & AO Research Institute \\
& Latvian Institute of Organic & Davos, CH \\
& Synthesis, LV & University of Erlangen- \\
& Riga Stradiňš University, LV & & Nuremberg, DE \\
FINEST & Tallinn University of & Aalto University & \\
TWINS & Technology, EE & Foundation, FI & \\
& Ministry of Economic Affairs & Forum Virium Helsinki, & \\
& and Communications, EE & FI & \\
\hline
\end{tabular}




\subsection{Doctoral students and Horizon 2020}

Doctoral students in science and technology fields for Estonia and Finland are at $0.7 \%$ and $1.3 \%$ of the 20-29 years aged population (Eurostat, last data from 2012). These countries have improved the performance in comparison to the previous EU research programme (FP7, Dashboard). For example, Estonia accumulated around $0.2 \%$ of total FP7 EC contribution, but in Horizon 2020 it has doubled its share (0.38\%, Fig. 1). Also, Finland has slightly improved from $1.9 \%$ to $2.2 \%$, while Latvia and Lithuania ( $0.3 \%$ doctoral students for both) remain at the previous around $0.1 \%$ level. Draft trend: countries with higher Doctoral students' ratio have higher potential for future growth - a topic for study in Horizon Europe.

There is a correlation between Horizon 2020 funding attributed to one Doctoral $(\mathrm{PhD})$ student and the number of total $\mathrm{PhD}$ students enrolled and graduated (Fig. 4). According to Lehman et all. (2013) Spearman's correlation coefficients are respectively 0.50 (moderate) and 0.68 (strong). One can conclude - a university investing more in research can attract more students and provides more possibilities for research education.
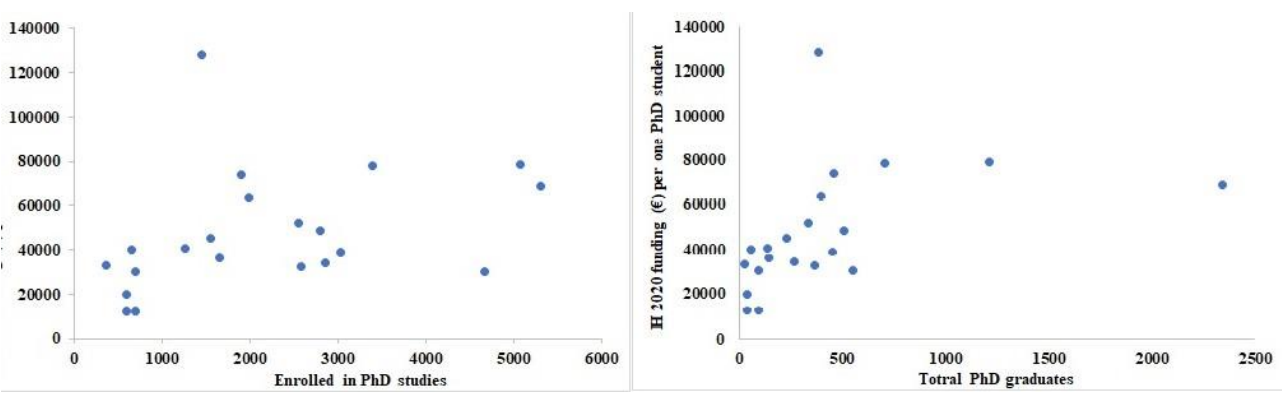

Figure 4. Correlation between Horizon 2020 funding and PhD intensity. Source: ETER \& Dashboard (2020).

\section{Universities and Sustainable development}

The next Horizon Europe programme is aimed at achieving Sustainable development goals (SDG, 2015). Therefore, it is interesting to look how universities cope with these goals today. In 2019 THE has published a ranking focusing on how HES are contributing to the Sustainable development goals. The list reflects 4671 HES performance against SDGs.

Fifteen Baltic - Nordic HES are included, half of them among top-100 (Fig. 5). The best are Swedish universities; from Baltics, only Latvian have submitted data on SDGs. A university's final overall score is calculated by combining its score for SDG 17 (mandatory) with its top three scores of other SDGs; therefore, all are not assessed against the same SDGs.

It is certainly worth emphasising the University of Gothenburg (Fig. 5, grey highlighted, not included in sample of this paper as ranks $7^{\text {th }}$ for Sweden). Hypothesis: mission based Horizon Europe programme could become a game-changer for university participation. 


\begin{tabular}{|c|l|c|c|c|c|c|c|c|c|c|}
\hline Rank & Name & Country & SDG3 & SDG4 & SDG5 & SDG8 & SDG9 & SDG13 & SDG16 & SDG17 \\
\hline 6 & University of Gothenburg & SE & 8 & 1 & 3 & $101-200$ & & 30 & 38 & 30 \\
\hline 7 & KTH Royal Institute of Technology & SE & & 37 & $101-200$ & 2 & 3 & 9 & & 14 \\
\hline 15 & University of Helsinki & FI & 93 & $101-200$ & 31 & 42 & 90 & 11 & 4 & 9 \\
\hline 19 & Aalto University & FI & $201-300$ & 87 & $101-200$ & $101-200$ & 10 & 27 & $101-200$ & 5 \\
\hline 53 & University of Bergen & NO & 39 & $201-300$ & 87 & $101-200$ & $101-200$ & & 74 & 59 \\
\hline 75 & University of Eastern Finland & FI & 81 & $201-300$ & $101-200$ & $101-200$ & $101-200$ & $101-200$ & 84 & $101-200$ \\
\hline 92 & University of Latvia & LV & $301+$ & $201-300$ & $101-200$ & 32 & $101-200$ & 97 & 80 & 49 \\
\hline 97 & Aalborg University & DK & 77 & 19 & 45 & & 34 & 48 & & $201-300$ \\
\hline
\end{tabular}

Figure 5. Baltic - Nordic universities' commitment to SGDs. Source: THE (2020).

\section{References}

Cordis - EU research results. Retrieved April 2, 2020 from https://cordis.europa.eu/projects

CWUR - Center for World University Rankings 2019-2020. Retrieved January 10, 2020 from https://cwur.org/2019-2020.php.

Dashboard - EC Funding \& tender opportunities. Retrieved March 17, 2020 from https://webgate.ec.europa.eu/dashboard/hub/.

ETER - European Tertiary Education Register. Retrieved January 10, 2020 from https://www.eter-project.com/\#/home.

European Commission - Horizon 2020 programme analysis. Retrieved April 2, 2020 from https://ec.europa.eu/info/research-and-innovation/strategy/support-policymaking/support-eu-research-and-innovation-policy-making/evaluation-impactassessment-and-monitoring/horizon-2020_en\#monitoring.

Eurostat - European Commission Database. Retrieved January 10, 2020 from https://ec.europa.eu/eurostat/data/database.

Geske, A., Bērzinna, D. (2017). A two-speed Europe in the Area of Research. $21^{\text {st }}$ World Multi-Conference on Systemics, Cybernetics and Informatics (WMSCI 2017), Vol 2, 4348.

Lehman, A., O'Rourke, N., Hatcher, L. \& Stepanski E. J. (2013). JMP for Basic Univariate and Multivariate Statistics: Methods for Researchers and Social Scientists. SAS Press.

Magna Charta Universitatum (1988). Retrieved January 10, 2020 from http://www.magnacharta.org/resources/files/the-magna-charta/english.

QS - Quacquarelli Symonds World University rankings. Retrieved January 10, 2020 from https://www.topuniversities.com/university-rankings/world-university-rankings/2020.

SDG - UN Sustainable Development Goals (2015). Retrieved January 10, 2020 from https://www.un.org/sustainabledevelopment/sustainable-development-goals.

THE - The Times Higher Education World University Rankings 2020. Retrieved January 10, 2020 from https://www.timeshighereducation.com/world-universityrankings.

Worldometer. Retrieved April 2, 2020 from https://www.worldometers.info. 